\title{
Prediction Comparison of Flow Resistance in Channels with Rounded and Angular Coarse Rough Beds
}

\author{
${ }^{1}$ Zahra Askari, ${ }^{2}$ Hossein Samadi-Boroujeni, ${ }^{2}$ Rouhollah Fattahi-Nafchi, ${ }^{3}$ Neda Yousefi \\ ${ }^{4}$ Saeid Eslamian, ${ }^{5 *}$ Kaveh Ostad-Ali-Askari \\ ${ }^{1}$ Water Engineering Department, Ferdowsi University of Mashhad, Mashhad, Iran \\ ${ }^{2}$ Water Engineering Department, Shahrekord University, Shahrekord, Iran \\ ${ }^{3}$ Water Engineering Department, Macquarie University, Sydney, Australia \\ ${ }^{4}$ Water Engineering Department, Isfahan University of Technology, Isfahan, Iran \\ ${ }^{*}$ Department of Civil Engineering, Isfahan (Khorasgan) Branch, Islamic Azad University, Isfahan, Iran \\ Koa.askari@khuisf.ac.ir, Kaveh.oaa2000@gmail.com
}

Abstract: Manning's (n) is a coefficient representing quantity of friction which a channel applies against flow. In general, it explains how roughness is a channel. This experimental research tries to explore (n) by making 8 $\mathrm{m}$ length, $40 \mathrm{~cm}$ width and $40 \mathrm{~cm}$ height laboratory flume with adjustable slope. The flume was used to carry out a total of 72 experiments with 4 different slopes, 3 different flow rates and 2 types of sorting with angular and rounded aggregates. The results showed that the roughness coefficient of the beds covered with angular grains is on average $6.68 \%$ higher than that of the beds covered with rounded grains. Also, for a constant value, if the flow rate increases, Manning roughness coefficient will also decrease. It was also shown that parameters such as relative submergence, grain size and slope affect the roughness coefficient. Based on the results of this research, it can be concluded that in all of the experiments, the shear stress of the bed with the rounded particles declined $3.62 \%$ as compared to angular particles.

Keywords: Manning roughness coefficient, angular, rounded, rough bed

\section{INTRODUCTION}

So far, many studies have been performed to estimate the roughness coefficient of flow resistance due to the size of the particles, but in these studies, the effect of particle shape is not clearly understood. In alluvial channels of Paul and Jarvis (1976), Bathurst and Ferguson (1986), Petit (1990), San Verida (1991), Robert et al (1992), Prandtl-Karman principle and vertical velocity distribution were used that velocity can be dependent on the logarithm of height. Shear velocity can be calculated according to velocity distribution equations.

$$
\boldsymbol{u}^{*}=\sqrt{\frac{\mathbf{t}}{r}}
$$

where $u^{*}$ is shear velocity, $\tau$ is shear stress and $\rho$ is water density. In totally rough flows, local (spatial) estimation of shear velocity determines the dynamics of sedimentation which may seriously deviate from the results of equation (2). It is due to the significant variability of bed roughness.

$$
u^{*}=\sqrt{g R S_{f}}
$$

where $u^{*}$ is shear velocity, $\mathrm{g}$ is gravity, $\mathrm{R}$ is hydraulic radius and $\mathrm{S}_{\mathrm{f}}$ is the energy line slope.

Some literatures studying the effect of sediment particle sizes of the bed and the waterway walls on Manning roughness coefficient (n) are: Strickler (1923), Meyer-Peter and Mueller (1948), Keulegan (1938), Henderson (1966), Anderson et.al (1970) and Huger (1970). They suggested that Manning roughness coefficient is just 
a function of average bed particle size. Strickler (1923) was the first to present the following equation for determining Manning roughness coefficient (n) based on his experimental observations about the rivers with eroded rocky beds in Switzerland:

$$
n=c_{n} K_{s}^{\frac{1}{6}}
$$

where $\mathrm{C}_{\mathrm{n}}$ is a factor dependent on the definition of $\mathrm{K}_{\mathrm{s}}$ measurement unit, the type of the material covering the floor and walls of the channel. In rivers and sedimentary channels where the bed is made of non-cohesive materials (sand, gravel, pebbles, etc.), the diameter of the particles forming the channel wall (D) can be used instead of $\mathrm{K}_{\mathrm{s}}$ (Mahmoodian Shooshtari, 2006). On the effect of slope on Manning roughness coefficient, Hessel, Jeten and Guanxo (2003) conducted some experiments to estimate Manning roughness coefficient for the steep slopes. Jarrett (1984) proposed the following equation to estimate the Manning coefficient:

$$
n=0.39 S_{f}{ }^{0.38} R^{-0.16}
$$

where $\mathrm{S}_{\mathrm{f}}$ is the slope of the energy line and $\mathrm{R}$ is the hydraulic radius in feet. Hydraulically, the flow can be steady, transient or rough. Hydraulically, a steady flow occurs when surficial disturbances are so small that all the roughness elements are generally immersed below the linear layer (Chow, 1959).

Graf (1998), Schlichting and Gersten (2000) defined the flow with smooth, transient and rough beds as follows:

$$
\begin{gathered}
0<\frac{u^{*} K_{s}}{v}<5 \\
5<\frac{u^{*} K_{s}}{v}<70 \\
\frac{u^{*} K_{s}}{v}>70
\end{gathered}
$$

where $\mathrm{u}^{*}$ is the shear velocity and $\mathrm{k}$ is the roughness height. Thus, velocity distribution is affected by bed roughness and viscosity (Chow, 1959).

\section{Materials AND Methods}

According to the research objectives, the experiments were conducted using a flume located at Hydraulic Laboratory of Shahrekord University. The flume was rectangular with adjustable slope (length, width and height of $8 \mathrm{~m}, 40 \mathrm{~cm}$ and $40 \mathrm{~cm}$, respectively). To perform the tests, both particle shapes (angular and rounded) were provided in three average grain sizes $(10,20$ and $30 \mathrm{~mm})$. Then, for each particle shape, the flume bed was uniformly covered with the intended grading between its both ends with a height that was at least twice the height of $\mathrm{D}_{50}$. Then by creating a uniform flow through the gate located at the end of the flume, water depth readings according to the 4 tested slopes of $0.005,0.01,0.015$ and 0.02 , and the three (initial, intermediate, and final) flow rates of 10, 20 and 30 liters per second, three sections were considered along the flume at a spacing of $2 \mathrm{~m}$. Also, the velocity at every section was measured using pitot tube at $0.2,0.6$ and 0.8 of the water depth at three points of the width of the flume. In order to roughen the river bed by using of sediments, three different gradations in 10, 20 and 30 millimeter sizes were used. Rounded sediments (collected from the river) and angular sediments (produced from the crusher) were employed after they were prepared and graded.

Figure1,2 show an example of angular and rounded particles with 2 gradations, respectively. 
Prediction Comparison of Flow Resistance in Channels with Rounded and Angular Coarse Rough Beds

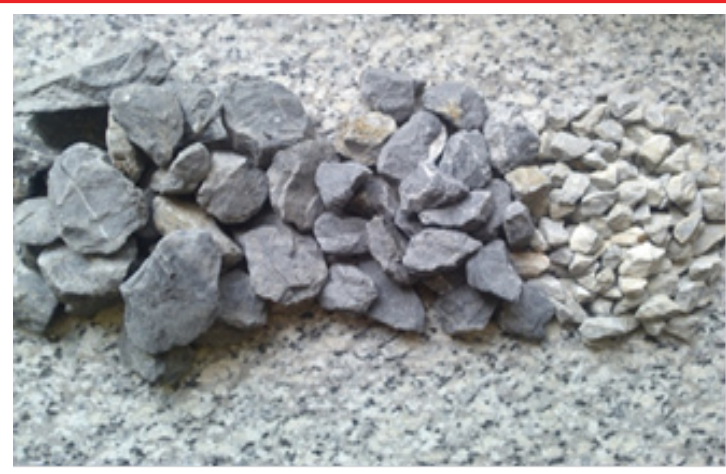

Fig1. An example of a angular particles size

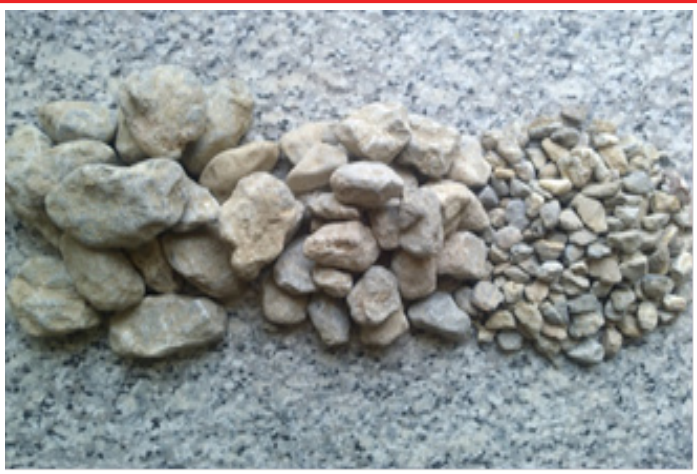

Fig2. An example of a rounded particles size

The figure 3,4 show pitot tube and flume used.

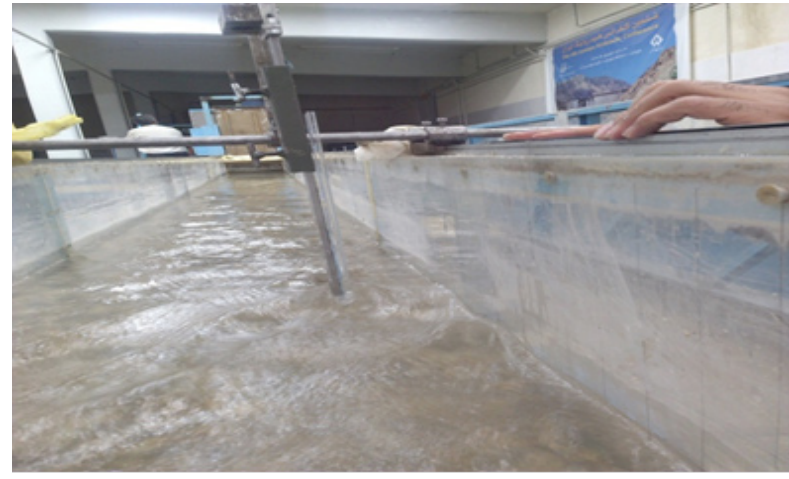

Fig 3. Pitot tube

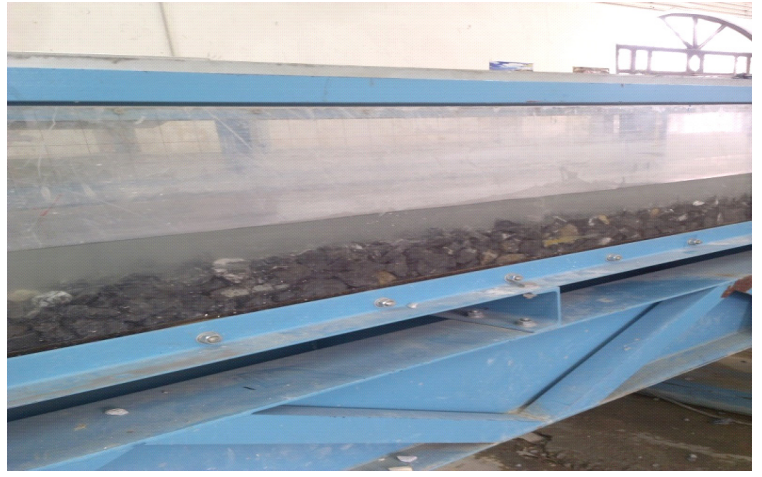

Fig 4. Flume used

The factors affecting Manning roughness coefficient of rough beds are:

$$
n=f\left(\rho, v, y, \mu, g, b, k_{s}, s_{0}, S F\right)
$$

where $n$ is Manning roughness coefficient, $\rho$ is unit volume of water, $\mathrm{v}$ is average flow velocity, $\mathrm{y}$ is flow depth, $\mu$ is mechanical viscosity coefficient of water, $g$ is gravity, and $b$ is the width of the channel that was constant in this study $(b=0.4 m) . \mathrm{k}_{\mathrm{s}}$ is the average size of the bed particles, $\mathrm{s}_{0}$ is the slope of channel floor, and SF is the shape factor of sedimentary aggregates.

Using Buckingham's relation and by selecting the three variables of $\rho$, vand y as the repetitive variables, equation 4 can be transformed to equation 5 that includes 5 parameters:

$$
n=f\left(\mathrm{Re}_{,} \mathrm{Fr}_{,} S_{\mathrm{o}}, \frac{R}{K_{s}}, S F\right)
$$
where Re is the Reynolds number, $\mathrm{Fr}$ is the Froude number of flow, $\mathrm{S}_{0}$ is the channel bottom slope, $\frac{R}{K_{S}}$ is the
parameter of relative submergence and $\mathrm{SF}$ is the shape factor of the aggregates.

\section{RESULTS AND Discussion}

The effect of relative submergence on Manning roughness coefficient

In order to investigate the effect of the shape of sedimentary particles on Manning roughness coefficient, the (n) diagram was plotted versus $\frac{R}{K_{S}}$ in Fig. 5 for different flow rates for the bed sediments with the same grading. 


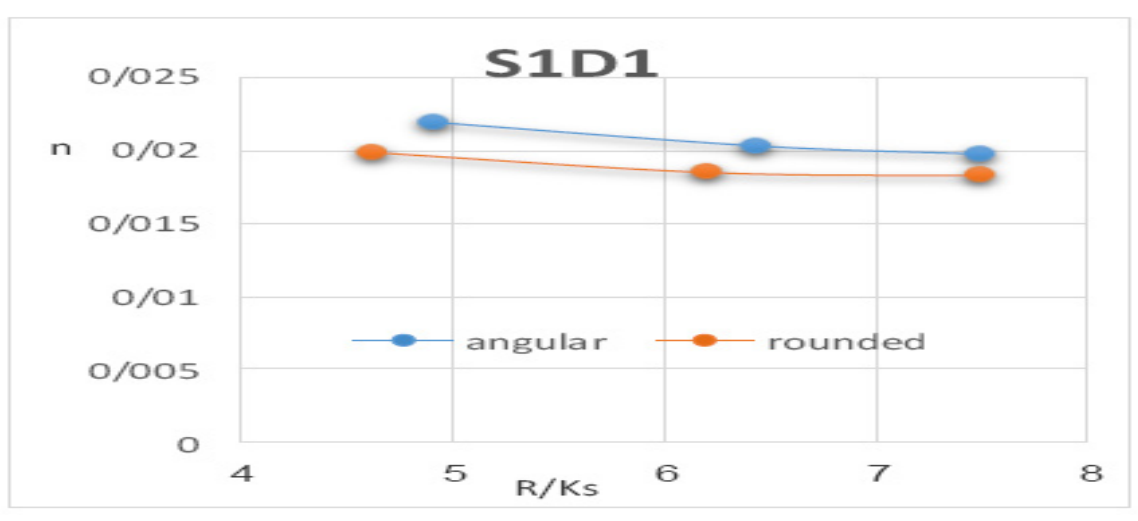

Fig5. Manning roughness coefficient of the particle size $10 \mathrm{~mm}$ with slope 0.01

As the graph shows, In the same hydraulic conditions, the flow lines are more easily separated from the surface of the angular particles compared to rounded particles, i.e. the separation points of angular particles occur before that of the rounded ones. Thus, the detachment zone created behind every angular particle is larger than that of a rounded particle. As a result, the pressure difference between the front and behind the angular particles is more than that of the rounded particles. As a result, on a rough bed, the total drag forces for angular particles are higher than that of the rounded particles; in another word, the frictional loss of angular particles is higher than that of rounded particles which is consistent with the findings of the study by Shafaei Bajestan (2010).

\section{The Effect of Grains Size on Manning Roughness Coefficient}

Along a rough bed in the flow direction, both the frictional drag force and the pressure drag of the fluid affect the bed. At the same hydraulic condition, the greater the roughness of the bed, the higher the drag force, since the grain surfaces facing the flow is increased. Therefore, at the same hydraulic conditions, if the particle size increases, Manning roughness coefficient increases. As a result, the drag force becomes smaller which results in reduced drag pressure. Therefore, increased flow rate and depth lead to decreased total drag force, and thereby, decreases the Manning roughness coefficient (Eslamian S. and et al. 2017 \& Shayannejad M. and et al. 2015 \& Ostad-Ali-Askari and et al. 2015).

As the diagrams in Fig. 6 shows, by increasing the particle size, the Manning roughness coefficient increases; and the increase in roughness coefficient of angular grains is much higher than that of the rounded grains.

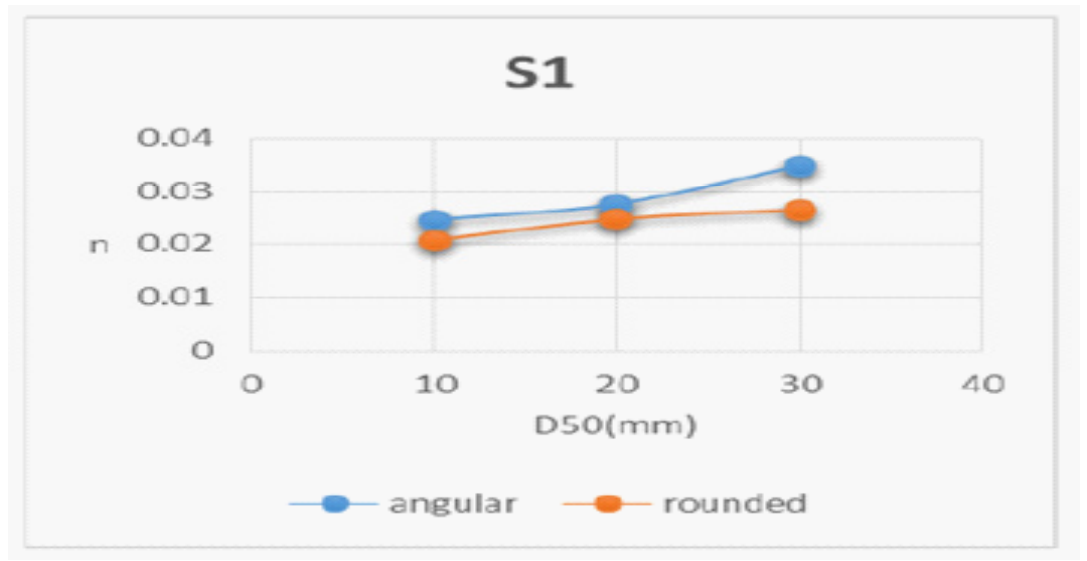

Fig6. Manning roughness coefficient with slope 0.005 
Prediction Comparison of Flow Resistance in Channels with Rounded and Angular Coarse Rough Beds The table 1 shows Using SPSS, and with regard to Manning roughness coefficient (n) as the dependent variable, $\frac{R}{K_{S}}, \mathrm{~S}_{0}$, and $\mathrm{D}$ as independent variables, linear regression analysis was carried out on both rounded and angular beds.

Table 1. Equivalent roughness on two round and sharp edge beds

\begin{tabular}{|c|c|c|}
\hline Rounde $\alpha=\frac{k_{s}}{D_{\text {so }}}$ & Angular $\alpha=\frac{k_{s}}{D_{50}}$ & Particle Size \\
\hline 4.4 & 5.17 & 20 \\
3.06 & 5 & 30 \\
2.14 & 4.09 & \\
\hline
\end{tabular}

Table 2. Recommended regression equation (multi variant) of Manning roughness coefficient determination in two round and sharp edge beds

\begin{tabular}{|c|c|c|}
\hline Fitted equation & \multicolumn{2}{|c|}{ R Square } \\
\hline$n=0.777 s-0.002 \frac{R}{K_{s}}+0.3$ & Angular & 0.906 \\
$n=0.723 S_{0}-0.001 \frac{R}{K_{s}}+0.025$ & Rounded & 0.857 \\
\hline
\end{tabular}

The table 2 shows This type of regression is a method for finding the relationship between the variable and a set of independent variables.

The equal roughness of the rivers is usually considered equal to a coefficient that is representative of the sedimentary grains of the bed, $k_{s}=\alpha D_{s}$. The value of $\alpha$ in the rivers with uniform bed materials is equivalent to 1 and $D_{50}$ is assumed as the representative size of the bed materials.

As is clear from the table, the larger the particle, the less the equivalent roughness. For angular beds, the value of this coefficient is higher.

Comparison of the velocity distribution for both rounded and angular cases

The flow with rough bed occurs when the roughness is 6 times $\delta$. In these types of flows, the shear Reynolds $\mathrm{Re}^{*}=\frac{x^{*} \boldsymbol{z}_{s}}{v^{2}}$ is also greater than 70. These types of flows are also called fully turbulent flows.

As diagram in Fig. 6 shows, the velocity near water surface is greater than the bottom depth of the bed which is due to the existence of secondary flows and fineness ratio.

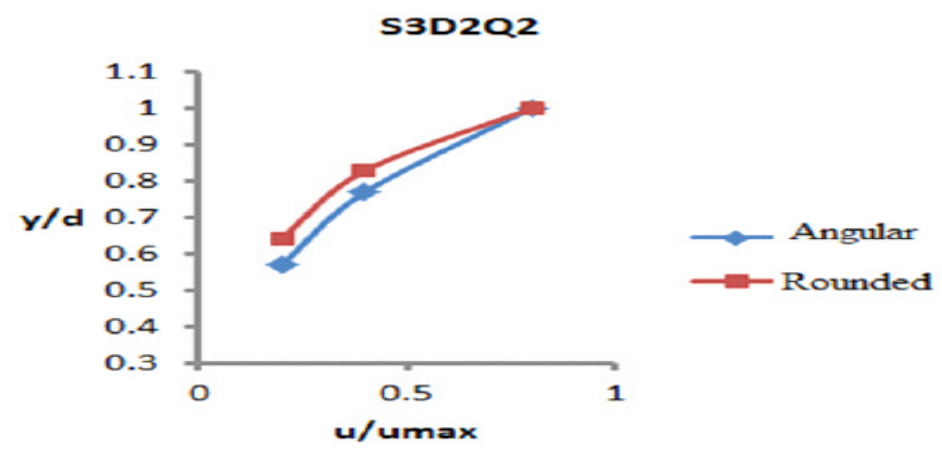

Fig7. Dimensionless velocity profiles with 0.015 a slope of $20 \mathrm{~mm}$ particle size and discharge of 20 liters per second

American Research Journal of Civil And Structural Engineering

Page 5 
Prediction Comparison of Flow Resistance in Channels with Rounded and Angular Coarse Rough Beds

Comparison of shear stress distribution of the bed for both rounded and angular cases

As the curve in Fig. 7 shows, the bed shear stress increased with increasing bed particle sizes and the shear stress of angular bed is more than the rounded bed. At the same hydraulic conditions, the flow lines are separated easier from the surfaces of angular particles than that of the rounded particles, i.e. the separation points of angular particles occur before that of the rounded aggregates. Consequently, the pressure difference between the two sides of angular particles is higher than that of the rounded particle. This causes the drag pressure of angular particles to be greater than that of the rounded particles. As a result, the total drag force acting on the rough bed for angular aggregates is higher than the rounded particles, or in other words, the friction losses of angular particles is more than that of the rounded particles. This causes the shear stress of angular particles to be higher than that of the rounded particles.

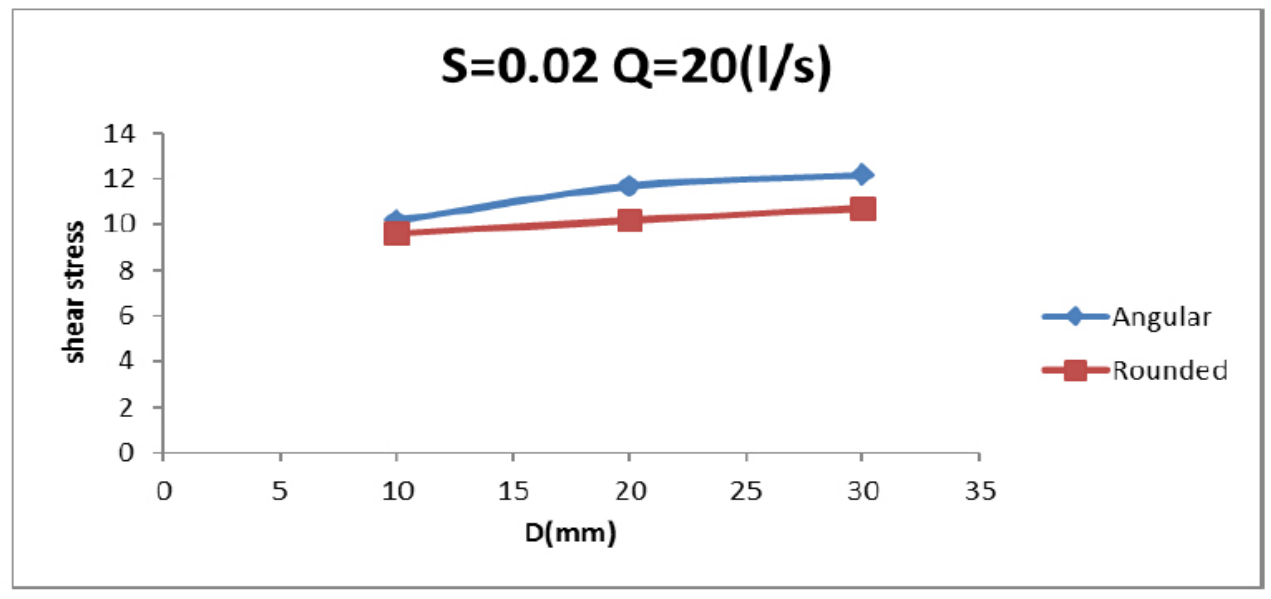

Fig8. shear stress with 0.02 slope when discharge is $20 \mathrm{l} / \mathrm{s}$

\section{Dimensionless Velocity Distribution; Angular and Rounded}

The dimensionless images of velocity distribution in Fig. 9 and 10 suggest that in the rounded bed the slope of velocity variations is milder than the slope of changes in the angular bed. These conditions resemble those of old and young rivers: the angular bed resembles the young rivers whereas the rounded bed is similar to the old rivers.

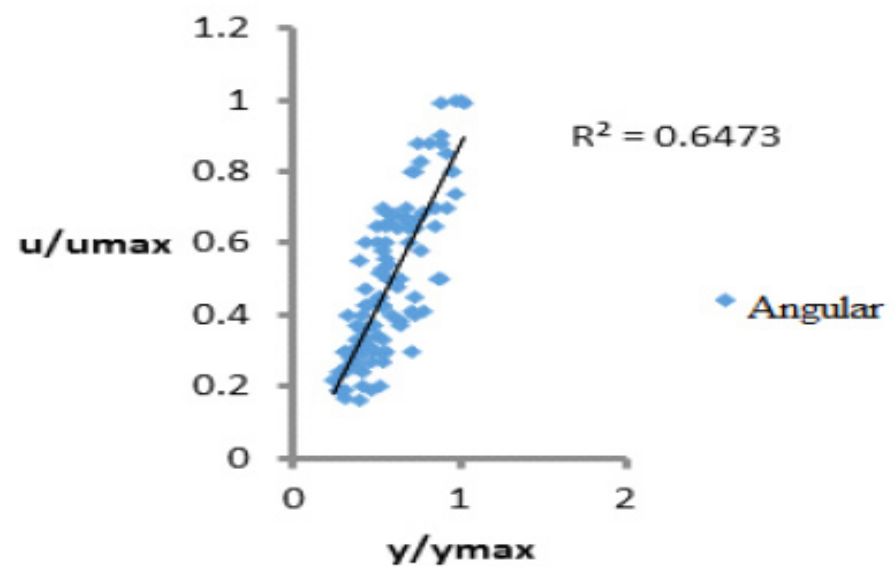

Fig9. Chart dimensionless velocity distribution angular 


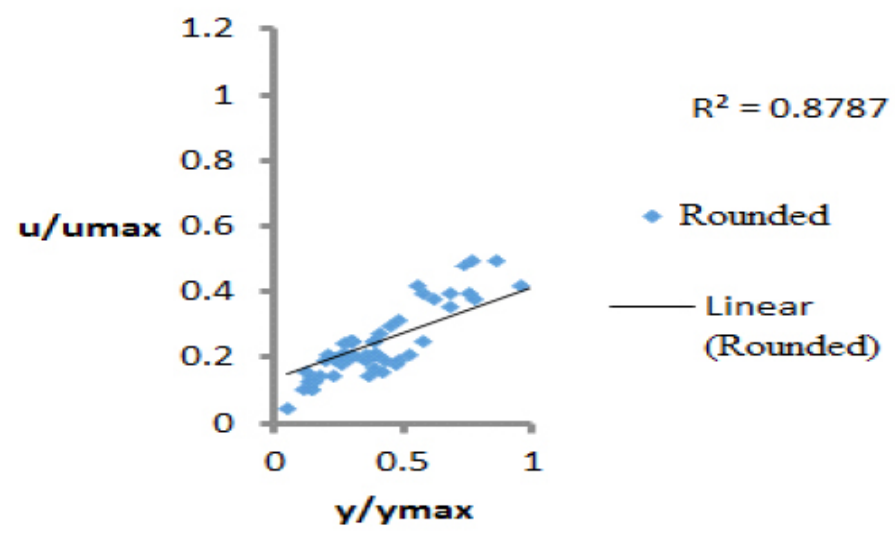

Fig10. Chart dimensionless velocity distribution rounded

The Effect of Deposit Particle Sizes on the Shear Velocity of Flow in the Angular and Rounded Beds

Fig. 11 to 13 show the variations of $u / u^{*}$ versus Reynolds boundary number $\left(\operatorname{Re}^{*}\right)$ in different gradations for the angular and rounded states. As implied by these Fig., with an increase in Re, the value of $u / u^{*}$ escalates. Moreover, $\mathrm{u} / \mathrm{u}^{*}$ is in an inverse relationship with Darcy-Weisbach factor (f) and Manning roughness coefficient in Fig. 12 and 17. Therefore, with an increase in Reynolds number, the Darcy-Weisbach factor and the Manning roughness coefficient decline. In addition, as the sizes of bed particles grow, the numerical value of $u / u^{*}$ as well as the Darcy-Weisbach factor and Manning roughness coefficient escalate. Shafa'i Bajestan and Yar Amadi (2009) also obtained the same results for 4 gradations with the slope. In addition, in this study, velocity profiles were plotted by drawing $\frac{u}{u_{\max }}$ versus $\frac{y}{d}$ where $u$ denotes the point velocity at a depth of $y$ in the bed, $\mathrm{u}_{\max }$ shows the maximum point velocity in each profile and finally $y$ stands for the depth of flow at the bed floor in each profile.

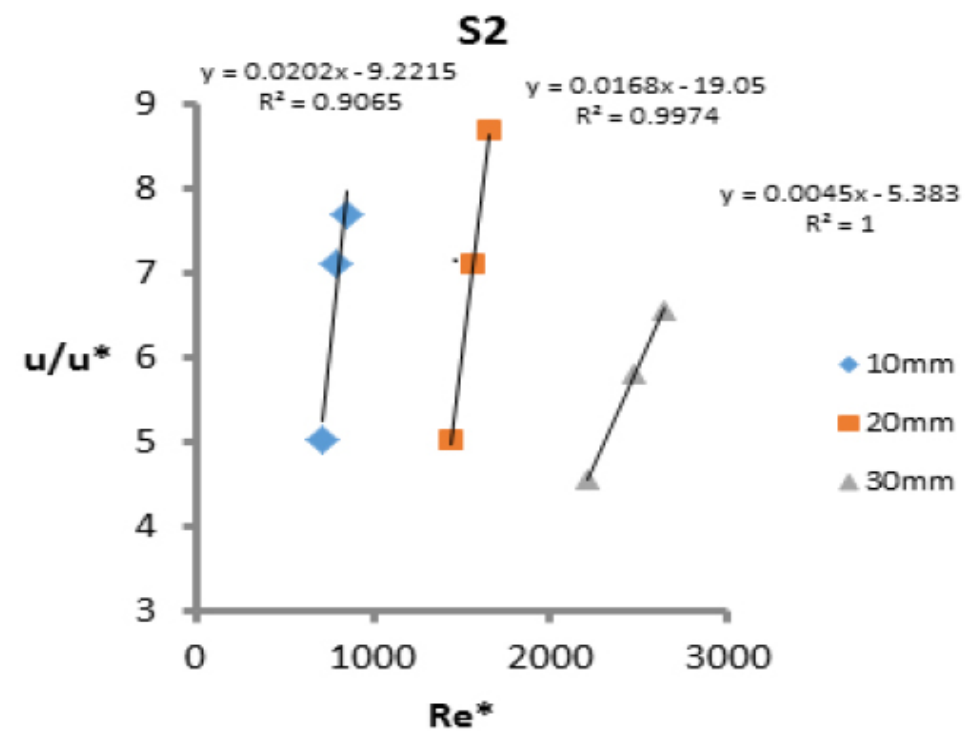

Fig11. variations of $u / u^{*}$ versus Re with a 0.01 slope and angular particles 
Prediction Comparison of Flow Resistance in Channels with Rounded and Angular Coarse Rough Beds

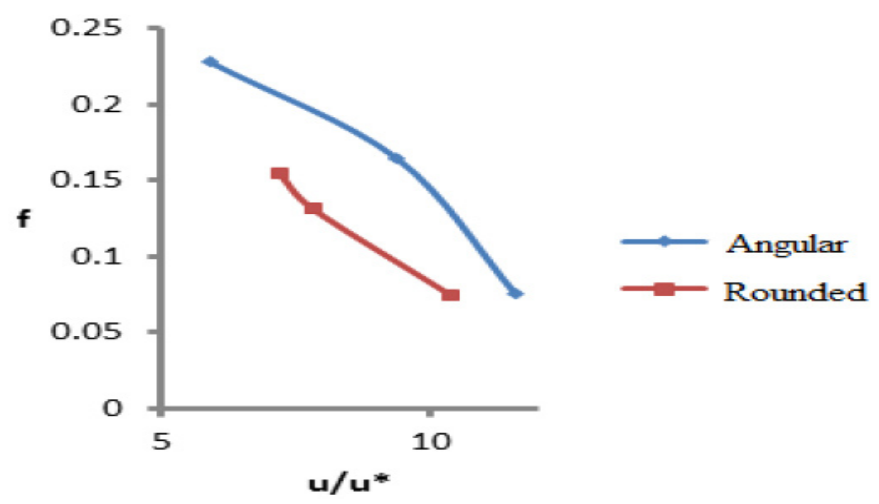

Fig12. The Darcy-Weisbach factor versus u/u* with a 0.005 slope and $20 \mathrm{~mm}$ particle size

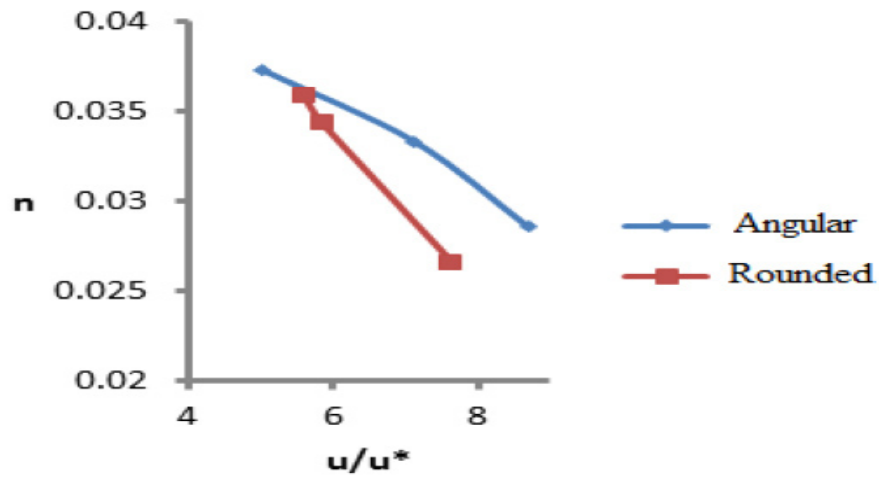

Fig13. Manning roughness coefficient versus $u / u^{*}$ with a 0.005 slope and $20 \mathrm{~mm}$ particle size

\section{LEGENDS}

\begin{tabular}{|c|c|}
\hline $\mathrm{n}$ & Manning roughness coefficient \\
\hline$\rho$ & Density of water \\
\hline $\mathrm{y}$ & Water depth \\
\hline $\mathrm{R}$ & Hydraulic radius \\
\hline $\mathrm{u}^{*}$ & Shear velocity \\
\hline $\mathrm{Re}$ & Froude number \\
\hline $\mathrm{Fr}$ & Maximum speed \\
\hline $\mathrm{u}_{\max }$ & Average speed \\
\hline $\mathrm{u}$ & Shear stress \\
\hline$\tau$ & Relative submergence \\
\hline$R_{\mathrm{s}}$ & Darcy-Weissbach factor \\
\hline $\mathrm{f}$ & Bed slope \\
\hline $\mathrm{S}_{0}$ & Particle size \\
\hline $\mathrm{D}$ & Roughness height \\
\hline $\mathrm{k}_{\mathrm{s}}$ & Correlation coefficient \\
\hline $\mathrm{R}^{2}$ & Gravity \\
\hline $\mathrm{g}$ & \\
\hline
\end{tabular}

American Research Journal of Civil And Structural Engineering 


\section{REFERENCES}

1. Askari Z. (2014); "Experimental study of flow in the open channel with angular and rounded coarse rough beds"; Master Thesis of Hydraulic Structures, Shahrekord University.

2. Afzalimehr H. and Anctil F. (1998); "Estimation of gravel-bed river flow resistance"; Journal of Hydraulic Engineering, 124 (10): 1054-1058.

3. Babaeyan Koopaei, K. Ervine, D. A. Carling, P. A. and Cao. Z. (2002); Velocity and turbulence measurements for two overbank flow events in River Severn. J. Hydr. Engrg. ASCE. 128 (10): 891-900.

4. Bathurst. J. C. (1982); Theoretical aspects of flow resistance in gravel-bed Rivers, edited by R. D. Hey. J. C. Bathurst and C. R. Thorne; 83-105; John Wiley. NY.

5. Biron. P. M. Robson. C. Lapointe. M. F. and Guskin. S. J. (2004); Comparing Earth Surface Processes and Landforms; 29. 1403-1415.

6. Cheng, N. S. (2002); Exponential formula for bedload transport; J Hydraul. Eng., 128(10):942-946.

7. Chien N. Wan Z. (1998). Mechanics of Sediment Transport; The American Society of Civil Engineers. ASCE Press.

8. Cheng. N. S. (2002); Exponential formula for bedload transport; J. Hydraul. Eng. 128(10); 942-946.

9. Chiu, C. L. and Chiou. J. D. (1986); Structure of 3-D flow in rectangular open- Channels. J. Hydraul. Eng. 112 (11); 1050.

10. Chow. V.T. (1959); Open-Channel Hydraulics; McGraw-Hill Book Co. Singapore, 680 pages; ISBN 0-07-085906-X.

11. Einstein, H. A. (1942); Formulas for the transportation of bed-load. Trans. Am. Soc. Civ. Eng. 107: 561-597.

12. Fathi-Moghadam, M. Bahrami-Yarahmadi, M.Shafaei Bajestan,M.(2010); Effect of Land Slope and Flow Depth on Retarding Flow in Gravel-Bed Lands. School of Water Science Engineering Shahid Chamran University, Ahwaz, Iran.

13. Ferro V. (1999); Evaluating friction factor for gravel bed channel with high boulder concentration; Journal of Hydraulic Engineering; Vol. 125: 771-778.

14. Graf, W. (1971); Hydraulics of sediment transport; McGraw-Hill, New York.

15. Guo, J. and Julien, P. Y. (2001). Turbulent velocity profiles in sediment laden flows. J. Hydraul. Res. 39(1): 11-23.

16. Gibson. A. H. (1909); On the depression of the filaments of maximum velocity in a stream flowing through an open channel; Proceeding of the Royal Society of London. Series: 149-159.

17. Garcia. M. H (editor). (2007). Sedimentation engineering Processes measurement. Modeling and Practice; ASCE Manual. No 110.1132.

18. Hey. R. D. (1979). Flow resistance in gravel-bed rivers. J. Hydraul. D IV. Am. Soc. C IV. Eng. 105(4):365-379.

19. Julien. P. Y. (1995); Erosion and sedimentation; Cambridge University Press. Cambridge. U. K. 1068.

20. Kironoto. B. and W. H Graf. (1994); Turbulence characteristics in rough uniform open channel flow; Proc. Instn. Civ .Engrs. Water Marit. et. al; Energy U.K. 112:316-348.

21. Knight. D. W. Demetriou. J. D. and Homed, M.E. (1984). Boundary shear in smooth rectangular channels; J. Hydr. Eng: 110 (4): 405-422. 
Prediction Comparison of Flow Resistance in Channels with Rounded and Angular Coarse Rough Beds

22. Keulegan GH (1938); Laws of turbulent flows in open channels; J. Res. Nat. Bureau of Standards; Vol. 21. No. 6. 707-741.

23. Keulegan. G. H. (1938); Laws of turbulent flow in open-channels; Natl. Bur. Stand. Circ. (U. S.). 21: 709-741.

24. Kim. S-C. Friedrichs. C.T. Maa. JP-Y. Wright. L.D. (2000); Estimating bottom stress in tidal boundary layer from Acoustic Doppler velocimeter data; J. Hydr. Engrg., ASCE. 126(6): 399-406.

25. Leighly. J. B. (1932); Toward a theory of the morphologic significance of turbulence in the flow of water in streams; Univ. of Calif. Publ Geography: 6 (1). 122.

26. Liu. P. L. F. (2006); Turbulent boundary-layer effects on transient wave propagation in shallow water; Proceedings of the Royal Society A. 462: 3481-3491.

27. MaGcvicar BJ. Roy AG. (2007). Hydrodynamics of forced riffle pool in a gravel bed river: 10 mean velocity and turbulence intensity. Water Resources Research 43: W 12401. DOI. 10. 1029/2006 WR005272.

28. Mahmoodiyan shooshtari.M. (2006). Principles of flow open channels.

29. Monin AS. Yalgom AM. (1971); Statistical Fluid Mechanics; Vol. 1 MIT Press: Cambridge. MA.

30. Meyer-Peter E. Mueller. R. (1948); Formulas for Bed Load Transport; Report on the Second Meeting of the International Association of Hydraulic Structures Research. Stockholm. Sweden: 6-39.

31. Nezu. I. and w. Rodi, (1985); Experimental study on secondary currents in open channel flow. Proceeding of the 21 IAHR Congress, Melborn, Australia: 115-119.

32. Rowinski. P. M. Aberle. J. and Mazurczyk. A, (2005); Shear velocity estimation in hydraulic research; Acta Geophysica Polonica, 53(4). 567-583.

33. Seckin, G. N.Seckin and R.G Yurtal (2006). Boundary shear stress analysis in smooth rectangular channels. Can. J. Civ. Eng. 33: 336-3420.

34. Schlichting, H. \& Gersten. K. (1998); Boundary-Layer Theory; Springer-Verlag. Berlin. Germany, 799 pages. ISBN 3-540-66270-7.

35. Soto. U. A. and Madrid Aris. M. (1994); Roughness Coefficient of Civil Engineering. New York, Vol.1.

36. Smart, G.M. (1999); Turbulent velocity profiles and boundary shear stress in gravel bed rivers". J. Hydraul. Eng. 106: 106-115.

37. Thompson. C. E. L. Amos. C. L. Jones. T. E. R. and Chaplin, J. (2003). The Manifestation of fluid-transmitted bed shear stress in a smooth annular flume, A Comparison of methods. J. Coastal Res. 19 (4): 1094-1103.

38. Wolf. J. (1999); The estimation of shear stresses from near-bed turbulent velocities for combined wave-current flows; Coastal Engineering 37: 529-543.

39. Yang. S-Q. Yu. J.X. and Wang, Y.Z. (2004); Estimation of diffusion coefficients lateral shear stress and velocity in open channels with complex geometry; Water Resources Research. AGU Vol. 40. No. 5. W05202.

40. Ostad-Ali-Askari, K., Shayannejad, M. 2015, Study of sensitivity of Autumnal wheat to under irrigation in Shahrekord, Shahrekord City, Iran. International Journal of Agriculture and Crop Sciences, 8 (4), 602-605.

41. Shayannejad, M., Akbari, N., Ostad-Ali-Askari, K. 2015, Study of modifications of the river physical specifications on muskingum coefficients, through employment of genetic algorithm. International Journal of Development Research, 5(3), 3782-3785. 
42. Ostad-Ali-Askari, K., Shayannejad, M. 2015, The Reviews of Einstein's Equation of Logarithmic Distribution Platform and the Process of Changes in the Speed Range of the Karkheh River, Khuzestan province, Iran. International Journal of Development Research, 5(3), 3786-3790.

43. Ostad-Ali-Askari, K., Shayannejad, M., Ghorbanizadee-Kharazi, H. 2015, Assessment of artificial neural network performance and exponential regression in prediction of effective rainfall, International Journal of Development Research, 5(3),3791-3794.

44. Shayannejad, M. Akbari, N. and Ostad-Ali-Askari, K. 2015, Determination of the nonlinear Muskingum model coefficients using genetic algorithm and numerical solution of the continuity. Int. J. of Science: Basic and Applied Research, 21(1),1-14.

45. Ostad-Ali-Askari, K., Shayannejad, M. 2015, The Study of Mixture Design for Foam Bitumen and the Polymeric and Oil Materials Function in Loose Soils Consolidation. Journal of Civil Engineering Research, 5(2), 39-44. DOI: $10.5923 /$ j.jce.20150502.04

46. Sayedipour, M., Ostad-Ali-Askari, K., Shayannejad, M. 2015, Recovery of Run off of the Sewage Refinery, a Factor for Balancing the Isfahan-Borkhar Plain Water Table in Drought Crisis Situation in Isfahan Province-Iran. American Journal of Environmental Engineering, 5(2): 43-46. DOI: 10.5923/j. ajee.20150502.02

47. Ostad-Ali-Askari, K., Shayannejad, M. 2015, Developing an Optimal Design Model of Furrow Irrigation Based on the Minimum Cost and Maximum Irrigation Efficiency. International Bulletin of Water Resources \& Development, 3(2), 18-23.

48. Shayannejad M, Ostad-Ali-Askari K. Optimization and its application in water resources management. Kankash publisher. First edition, 2015. ISBN: 978-600-136-248-4. Isfahan, Iran.

49. Ostad-Ali-Askari, K., Shayannejad, M. 2015, Presenting a Mathematical Model for Estimating the Deep Percolation Due to Irrigation. International Journal of Hydraulic Engineering, 4(1), 17-21. DOI: 10.5923/j. ijhe.20150401.03.

50. Ostad-Ali-Askari, K., Shayannejad, M. 2015, Usage of rockfill dams in the HEC-RAS software for the purpose of controlling floods. American Journal of Fluid Dynamics, 5(1), 23-29. DOI: 10.5923/j.ajfd.20150501.03.

51. Ostad-Ali- Askari, K., Shayannejad, M. 2015, The effect of heterogeneity due to inappropriate tillage on water advance and recession in furrow irrigation. Journal of Agricultural Science, 7(6), 127-136.

52. Shayannejad, M., Ostad-Ali-Askari, K. 2015, Effects of magnetized municipal effluent on some chemical properties of soil in furrow irrigation. International Journal of Agriculture and Crop Sciences, $8(3), 482-489$.

53. Ostad-Ali-Askari, K., Shayannejad, M. 2015, Optimal design of pressurized irrigation laterals installed on sloping land. International Journal of Agriculture and Crop Sciences, ISSN 2227-670X. 8(5), 792-797.

54. Ostad-Ali-Askari K, Shayannejad M, Eslamian S, Navab-Pour B. 2016, Comparison of solution of Saint-Venant equations by characteristics and finite difference methods for unsteady flow analyzing in open channel. International Journal of Hydrology Science and Technology, 6(3), 9-18.

55. Ostad-Ali-Askari K, Shayannejad M, Eslamian S, et al. 2017, Deficit Irrigation: Optimization Models. Management of Drought and Water Scarcity. Handbook of Drought and Water Scarcity, Taylor \& Francis Publisher, USA. Vol. 3. $1^{\text {th }}$ Edition, pp: 373-389.

56. Eskandari S, Hoodaji M, Tahmourespour A, Abdollahi A, Mohammadian-Baghi T, Eslamian S, Ostad-Ali-Askari K. 2017, Bioremediation of Polycyclic Aromatic Hydrocarbons by Bacillus Licheniformis ATHE9 and Bacillus Mojavensis ATHE13 as Newly Strains Isolated from Oil-Contaminated Soil. Journal of Geography, Environment and Earth Science International, 11(2): 1-11.

American Research Journal of Civil And Structural Engineering

Page 11 
Prediction Comparison of Flow Resistance in Channels with Rounded and Angular Coarse Rough Beds

57. Shayannejad M, Ostad-Ali-Askari K, Eslamian S, et al. 2017, Development of a new method for determination of infiltration coefficients in furrow irrigation with natural non-uniformity of slope. Sustain. Water Resour. Manag., 3(2): 163-169.

58. Shojaei N, Shafaei-Bejestan M, Eslamian S, Marani-Barzani M, P. Singh V, Kazemi M, Ostad-Ali-Askari K. 2017, Assessment of Drainage Slope on the Manning Coarseness Coefficient in Mountain Area. International Journal of Constructive Research in Civil Engineering (IJCRCE), 3(1): 33-40.

59. Bahmanpour H, Awhadi S, Enjili J, Eslamian S, Ostad-Ali-Askari K. 2017, Optimizing Absorbent Bentonite and Evaluation of Contaminants Removal from Petrochemical Industries Wastewater. International Journal of Constructive Research in Civil Engineering (IJCRCE), 3(2): 34-42.

60. Shayannejad M, Eslamian S, Gandomkar A, Marani-Barzani M, Amoushahi-Khouzani M, Majidifar Z, Rajaei-Rizi F, Kazemi M, P. Singh V, Dehghan SH, Shirvani-Dastgerdi H.R, Norouzi H, Ostad-Ali-Askari K. 2017, A Proper Way to Install Trapezoidal Flumes for Measurements in Furrow Irrigation Systems. International Journal of Research Studies in Agricultural Sciences (IJRSAS), 3(7): 1-5.

61. Dehghan Sh, Kamaneh S.A.A., Eslamian S, Gandomkar A, Marani-Barzani M, Amoushahi-Khouzani M, Singh V.P., Ostad-Ali-Askari K. 2017, Changes in Temperature and Precipitation with the Analysis of Geomorphic Basin Chaos in Shiraz, Iran. International Journal of Constructive Research in Civil Engineering (IJCRCE), 3(2): 50-57.

62. Ostad-Ali-Askari K, Shayannejad M. 2016, FLOOD ROUTING IN RIVERS BY MUSKINGUM'S METHOD WITH NEW ADJUSTED COEFFICIENTS. International Water Technology Journal, IWTJ, 6(3): 189-194.

63. Ostad-Ali-Askari K, Shayannejad M, Ghorbanizadeh-Kharazi H. 2017, Artificial Neural Network for Modeling Nitrate Pollution of Groundwater in Marginal Area of Zayandeh-rood River, Isfahan, Iran. KSCE Journal of Civil Engineering, 21(1):134-140. Korean Society of Civil Engineers. DOI 10.1007/s12205-016-0572-8.

64. Shayannejad M, Ostad-Ali-Askari K, Ramesh A, Singh V.P., Eslamian S. 2017, Wastewater and Magnetized Wastewater Effects on Soil Erosion in Furrow Irrigation. International Journal of Research Studies in Agricultural Sciences (IJRSAS), 3(8): 1-14. http://dx.doi.org/10.20431/2454-6224.0308001.

65. Shayannejad M, Soltani-Toudeshki A.R, Arab M.A, Eslamian S, Amoushahi-Khouzani M, Marani-Barzani M, Ostad-Ali-Askari K. 2017, A Simple Method for Land Grading Computations and its Comparison with Genetic Algorithm (GA) Method. International Journal of Research Studies in Agricultural Sciences (IJRSAS), 3(8): 26-38.

66. Eslamian S, Ostad-Ali-Askari K, Soltani M. 2017, Climate Variability: Integration of Renewable Energy into Present and Future Energy Systems in Designing Residential Buildings. International journal of Rural Development, Environment and Health Research(IJREH), 1(2): 18-30.

67. Shayannejad M, Ostad-Ali-Askari K, Eslamian S, et al. 2017, Flow Hydraulic Investigation of the Wastewater on the Soil and Magnetic Field Effects in This Field. International Journal of Constructive Research in Civil Engineering (IJCRCE), 3(3): 1-15.

68. Shayannejad M, Eslamian S, Singh V.P., Ostad-Ali-Askari K, et al. 2017, Evaluation of Groundwater Quality for Industrial Using GIS in Mountainous Region of Isfahan Province, Koh-Payeh, Isfahan, Iran. International Journal of Constructive Research in Civil Engineering (IJCRCE), 3(3): 24-37.

69. Qian, Q., Eslamian, S., 2017, Streamflow Quality in Low-Flow Conditions, Ch. 20 in Handbook of Drought and Water Scarcity, Vol. 2: Environmental Impacts and Analysis of Drought and Water Scarcity, Ed. by Eslamian S. and Eslamian F., Francis and Taylor, CRC Press, USA, 375-386.

American Research Journal of Civil And Structural Engineering

Page 12 
Prediction Comparison of Flow Resistance in Channels with Rounded and Angular Coarse Rough Beds

70. Yousefi, N., Khodashenas, S. R., Eslamian, S. and Askari, Z. 2016. Estimating width of the stable channels using multivariable mathematical models, Arab. J. Geosci., Vol. 9, No. 321, DOI 10.1007/s12517-016-2322-0.

71. Biabanaki, M., Tabatabaei Naeini, A. and S. S. Eslamian, 2012, Effects of Urbanization on Stream Channels, Journal of Civil Engineering and Urbanism (JCEU), Vo. 2, No. 4, 136-142.

72. Eslamian, S., Gohari A., M. J. Zareian, 2006, Study the Benefits and Problems of the Use of Prefabricated Channels in the Irrigation Network of Isfahan, The Second Conference on Construction Experiences of the Hydraulic Constructions and Irrigation and Drainage Network, Tehran University, Iran.

73. Eslamian, S. S., 2008, Stream Ecology and Low Flows (SELF), International Journal of Ecological Economic \& Statistics, Ed., Special Issue Volume, CESER, Vol. 12, No. F08, 1-97.

74. Davari, A., Bagheri, A., Reyhani, M. N., Eslamian, S., 2017, Environmental Flows Assessment in Scarce Water Resources, Ch. 18 in Handbook of Drought and Water Scarcity, Vol. 2: Environmental Impacts and Analysis of Drought and Water Scarcity, Ed. by Eslamian S. and Eslamian F., Francis and Taylor, CRC Press, USA, 331-352.

75. Mohammadzade Miyab, N., Eslamian, S., Dalezios, N. R., 2017, River Sediment in Low Flow Condition, Ch. 21 in Handbook of Drought and Water Scarcity, Vol. 2: Environmental Impacts and Analysis of Drought and Water Scarcity, Ed. by Eslamian S. and Eslamian F., Francis and Taylor, CRC Press, USA, 387-408.

76. Vafakhah, M., Eslamian, S. and Khosrobeigi Bozchaloei, S., 2014, Low-Flow Hydrology, in Handbook of Engineering Hydrology, Ch. 20, Vol. 1: Fundamentals and Applications, Ed. By Eslamian, S., Francis and Taylor, CRC Group, USA, 433-453.

77. Fakhri, M., Dokohaki, H., Eslamian, S., Fazeli Farsani, I. and Farzaneh, M. R. 2014, Flow and Sediment Transport Modeling in Rivers, in Handbook of Engineering Hydrology, Ch. 13, Vol. 2: Modeling, Climate Changes and Variability, Ed. By Eslamian, S., Francis and Taylor, CRC Group, USA, 233-275.

78. Kałuża, T. and Eslamian, S. 2014, Impact of the Development of Vegetation on Flow Conditions and Flood Hazards, in Handbook of Engineering Hydrology, Ch. 21, Vol. 2: Modeling, Climate Changes and Variability, Ed. By Eslamian, S., Francis and Taylor, CRC Group, USA, 415-449.

79. Shaeri Karimi, S., Yasi, M., Cox, J. P., and Eslamian, S., 2014, Environmental Flows, in Handbook of Engineering Hydrology, Ch. 5, Vol. 3: Environmental Hydrology and Water Management, Ed. By Eslamian, S., Francis and Taylor, CRC Group, USA, 85-104.

80. Amiri, M.J., Bahrami, M., Hamidifar, H. and Eslamian, S., 2016. Modification of furrow Manning's roughness coefficient estimation by finite difference technique under surge and continuous flow. International Journal of Hydrology Science and Technology, Vol. 6, No. 3, 226-237.

81. Fathian, F., Dehghan, Z.., Eslamian, S., 2016, Evaluating the impact of changes in land cover and climate variability on streamflow trends (case study: eastern subbasins of Lake Urmia, Iran), J. Hydrology Science and Technology, Vol. 6, No. 1, 1-26.

82. Esmailzadeh, M., Heidarpour, M., Eslamian, S., 2015, Flow characteristics of sharp-crested side sluice gate, ASCE's Journal of Irrigation and Drainage Engineering, Vol. 141, No. 7, 10.1061/ (ASCE)IR.1943-4774.0000852.

83. Bahmani, R., Radmanesh, F., Eslamian, S., Khorsandi, M., Zamani, R., 2013, Proper Rainfall for Peak Flow Estimation by Integration of L-Moment Method and a Hydrological Model, International Research Journal of Applied and Basic Sciences, Vol. 4, No. 10, 2959-2967. 
Prediction Comparison of Flow Resistance in Channels with Rounded and Angular Coarse Rough Beds

84. Hadizadeh, R., Eslamian, S. and Chinipardaz, R., 2013, Investigation of long-memory properties in streamflow time series in Gamasiab River, Iran', Int. J. Hydrology Science and Technology, Vol. 3, No. 4, 319-350.

85. Bahmani, R., Radmanesh, F., Eslamian, S., Khorsandi, M. and Zamani, R., 2013, Proper Rainfall for Peak Flow Estimation by Integration of L-Moment Method and a hydrologic model, International Research Journal of Applied and Basic Sciences, Vol. 4 No. 10, 2959-2967.

86. Saatsaz, M., Azmin Sulaiman, W. N., Eslamian, S., Javadi, S., 2013, Development of a coupled flow and solute transport modelling for Astaneh-Kouchesfahan groundwater resources, North of Iran, International Journal of Water, Vol. 7, No.1/2, 80 - 103.

87. Galoie, M., Zenz, G., S. Eslamian and A. Motamedi., 2012, Numerical simulation of flood due to dam-break flow using an implicit method, International Journal of Environmental Science and Technology, Vol. 2, No. 2, 117-137.

88. Shaeri karimi, S., Yasi, M. and S. S. Eslamian, 2012, Use of Hydrological Methods for Assessment of Environmental Flow in a River Reach, International Journal of Environmental Science and Technology, 9(3), pp 549-558.

89. Eslamian, S. S., Ghasemizadeh, M., Biabanaki, M. and M. Talebizadeh, 2010, A principal component regression method for estimating low flow index, Water Resources Management, Vol. 24, No. 11, 2553-2566.

90. Eslamian, S. S. and M. Biabanaki, 2009, Low Flow Regionalization Models, International Journal of Ecological Economic \& Statistics, Special Issue on Stream Ecology and Low Flows (SELF), Vol. 12, No. F08, 82-97.

91. Eslamian, S. S., 2009, Editorial: An Ecologically Based Low Flow Review, International Journal of Ecological Economic \& Statistics, Special Issue on Stream Ecology and Low Flows (SELF), Vol. 12, No. F08, 1-6.

92. Modarres R. and S. S. Eslamian, 2006, Streamflow Time Series Modeling of Zayandehrud River, Iranian Journal of Science and Technology, Vol. 30, No. B4, 567-570.

93. Mostafazadeh-fard, B., Osroosh, Y. and S. S. Eslamian, 2006, Development and Evaluation of an Automatic Surge Flow Irrigation System, Journal of Agriculture and Social Sciences, Vol. 2, No. 3, 129-132.

94. Zareian, M.J., Eslamian, S.S., Gohari, A. and Hosseinipour, E.Z., 2014, Climate Change Impacts on Reservoir Inflow Using Various Weighting Approaches, World Environmental and Water Resources Congress, USA.

95. Shaeri Karimi, S., Eslamian, S. S. and R. Modarres, 2012, Estimating Environmental Flow for Millhaven Creek, Canada, 9th International Congress on Civil Engineering, Isfahan, Iran.

96. Biabanaki, M., S.S. Eslamian and A. Tabatabaei, 2012. Low flow regionalization by regression and hybrid methods. World Wide Workshop for Young Environmental Scientists, Arcueil, France.

97. Moravejalahkami, B., Mostafazadeh-Fard, B., Heidarpour, M., Abbasi, F., Eslamian, S. S. and E.Vazquez-Fernandez, 2010, The effects of variable inflow hydrographs on water saving in furrow irrigation using zero-inertia model, International Conference on Environmental Science and Technology, Bangkok, Thailand.

98. Biabanaki M. and S. S. Eslamian, 2005, Comparing Regional Flood and Low Flow Frequency by Index Flood and Hybrid Methods, International Conference on Human Impacts on Soils Quality Attributes in Arid \& Semiarid Regions, Isfahan University of Technology, Esfahan, Iran.

99. Biabanaki M. and S. S. Eslamian, 2005, Monthly Flow Forecasting by Time Series Models in Ghezelozen River, Iran-Korea Climate Modeling Workshop, Mashhad, Iran.

American Research Journal of Civil And Structural Engineering

Page 14 
Prediction Comparison of Flow Resistance in Channels with Rounded and Angular Coarse Rough Beds

100. Shabanlou, S., Rajabi, A., Eslamian, S. and Mousavi, S. F., 2012, Evaluation of empirical relationships for estimation of instantaneous peak flow Discharge in western catchments of IRAN, Iranian Water Research Journal, Vol. 6, No. 10, 215-219.

101. Eslamian, S. S., Tarkesh, S., 2009, Existing challenges by pollution increase of Zayandehroud Low Flow, Nama, 174-175.

102. Ayati, H., and S. Eslamian, 2008, Modeling of North Mahyar Plain Groundwater Using MODFLOW Model, Nama.

103. Eslamian S. S., Zarei A. and A. Abrishamchi, 2004, Regional estimation of low flows for Mazandaran River basin, Journal of Science and Technology of Agriculture and Natural Resources, Vol. 8, No. 2., 27-38.

104. Nosrati, K., Mohseni-saravi M., Eslamian S. S., Sharifi, F. and M. Mahdavi, 2004, Determination of Homogeneous regions for frequency analysis of low flows, Iranian Natural Resources Journal, Vol. 57, No. 1., 45-58.

105. Eslamian S. and A. Gohari, 2006, The Estimating of Low flow by the Use of Time Series Analysis, The 6th Iranian Hydraulic Conference, Shahrekord University, Iran.

106. Osroosh, Y., Mostafazadeh, B. and S. Eslamian, 2004, Design, manufacturing and calibration of automatic on and off water delivery system for surge flow irrigation. Proceedings of the First National Conference on Watershed and Soil \& Water Management, Kerman, Iran.

Citation: Zahra Askari, Hossein Samadi-Boroujeni, Rouhollah Fattahi-Nafchi, Neda Yousefi, Saeid Eslamian, Kaveh Ostad-Ali-Askari, "Prediction Comparison of Flow Resistance in Channels with Rounded and Angular Coarse Rough Beds", American Research Journal of Civil and Structural Engineering, vol 1, no. 1, pp. 1-15.

Copyright (c) Zahra Askari, Hossein Samadi-Boroujeni, Rouhollah Fattahi-Nafchi, Neda Yousefi, Saeid Eslamian, Kaveh Ostad-Ali-Askari, This is an open access article distributed under the Creative Commons Attribution License, which permits unrestricted use, distribution, and reproduction in any medium, provided the original work is properly cited. 